University of New Hampshire

University of New Hampshire Scholars' Repository

Center for Coastal and Ocean Mapping

Center for Coastal and Ocean Mapping

2015

\title{
Arctic Ocean Bathymetry: A Necessary Geospatial Framework
}

Martin Jakobsson

University of New Hampshire, Durham

Larry A. Mayer

University of New Hampshire, larry.mayer@unh.edu

Dave Monahan

University of New Hampshire, Durham

Follow this and additional works at: https://scholars.unh.edu/ccom

Part of the Oceanography and Atmospheric Sciences and Meteorology Commons, and the Tectonics and Structure Commons

\section{Recommended Citation}

M. Jakobsson, L. Mayer, and D. Monahan, "Arctic ocean Bathymetry: A necessary Geospatial framework," ARCTIC, vol. 68, no. 5, p. 41, Jan. 2015.

This Journal Article is brought to you for free and open access by the Center for Coastal and Ocean Mapping at University of New Hampshire Scholars' Repository. It has been accepted for inclusion in Center for Coastal and Ocean Mapping by an authorized administrator of University of New Hampshire Scholars' Repository. For more information, please contact Scholarly.Communication@unh.edu. 


\title{
Arctic Ocean Bathymetry: A Necessary Geospatial Framework
}

\author{
Martin Jakobsson, ${ }^{1}$ Larry Mayer ${ }^{2}$ and David Monahan ${ }^{2}$
}

(Received 26 May 2014; accepted in revised form 8 December 2014)

\begin{abstract}
Most ocean science relies on a geospatial infrastructure that is built from bathymetry data collected from ships underway, archived, and converted into maps and digital grids. Bathymetry, the depth of the seafloor, besides having vital importance to geology and navigation, is a fundamental element in studies of deep water circulation, tides, tsunami forecasting, upwelling, fishing resources, wave action, sediment transport, environmental change, and slope stability, as well as in site selection for platforms, cables, and pipelines, waste disposal, and mineral extraction. Recent developments in multibeam sonar mapping have so dramatically increased the resolution with which the seafloor can be portrayed that previous representations must be considered obsolete. Scientific conclusions based on sparse bathymetric information should be re-examined and refined. At this time only about $11 \%$ of the Arctic Ocean has been mapped with multibeam; the rest of its seafloor area is portrayed through mathematical interpolation using a very sparse depth-sounding database. In order for all Arctic marine activities to benefit fully from the improvement that multibeam provides, the entire Arctic Ocean must be multibeam-mapped, a task that can be accomplished only through international coordination and collaboration that includes the scientific community, naval institutions, and industry.
\end{abstract}

Key words: bathymetry; Arctic Ocean; mapping; oceanography; tectonics

RÉSUMÉ. Une grande partie de l'océanographie s'appuie sur l'infrastructure géospatiale établie à partir de données bathymétriques recueillies par des navires en route, données qui sont ensuite archivées et transformées en cartes et en grilles numériques. En plus de revêtir une importance essentielle sur le plan de la géologie et de la navigation, la bathymétrie, soit la profondeur du plancher sous-marin, est un élément fondamental de l'étude de la circulation en eaux profondes, des marées, de la prévision des tsunamis, des remontées d'eau, des ressources halieutiques, de l'action des vagues, du transport de sédiments, des changements environnementaux et de la stabilité des talus, en plus de la sélection de l'emplacement des plateformes, des câbles, des pipelines ainsi que de l'élimination des déchets et l'extraction minière. En raison des progrès récents réalisés en matière de cartographie par sonars multifaisceaux, la résolution avec laquelle le plancher sous-marin peut être représenté s'est améliorée à un point tel que les anciennes représentations doivent être considérées comme désuètes. Les conclusions scientifiques fondées sur des données bathymétriques clairsemées devraient être réexaminées et raffinées. Pour l'instant, seulement environ $11 \%$ de l'océan Arctique a été cartographié à l'aide de multifaisceaux. Le reste de son plancher sous-marin est représenté au moyen d'une interpolation mathématique faisant appel à des données très clairsemées de sondages en profondeur. Pour que toutes les activités maritimes de l'Arctique bénéficient pleinement des améliorations qu'offrent les multifaisceaux, la totalité de l'océan Arctique doit être cartographiée à l'aide de multifaisceaux, tâche qui ne peut s'accomplir qu'en présence d'une coordination et d'une collaboration internationales faisant appel à la communauté scientifique, aux institutions navales et à l'industrie.

Mots clés : bathymétrie; océan Arctique; cartographie; océanographie; tectonique

Traduit pour la revue Arctic par Nicole Giguère.

\section{INTRODUCTION}

Knowledge of Earth's underwater topography through bathymetric measurements is one of several critical components of the geospatial framework required for most Earth system studies. As interest grows in developing a sustainable observation network of Earth system parameters, it is easy to overlook the importance of this geospatial framework; however, not only is it a major part of the essential infrastructure on which all other science rests, but it also forms a critical boundary condition needed to position most environmental observations within an accurate spatial context. At the largest scale, bathymetry provides the fundamental information from which the tectonic setting can be determined. At finer scales, it provides a longterm record of the interactions of bottom currents, ice,

\footnotetext{
${ }^{1}$ Corresponding author: Department of Geological Sciences, Stockholm University, 10691 Stockholm, Sweden; martin.jakobsson@geo.su.se

${ }^{2}$ Center for Coastal and Ocean Mapping, University of New Hampshire, Chase Ocean Engineering Lab, 24 Colovos Road, Durham, New Hampshire 03824, USA

(C) The Arctic Institute of North America
} 

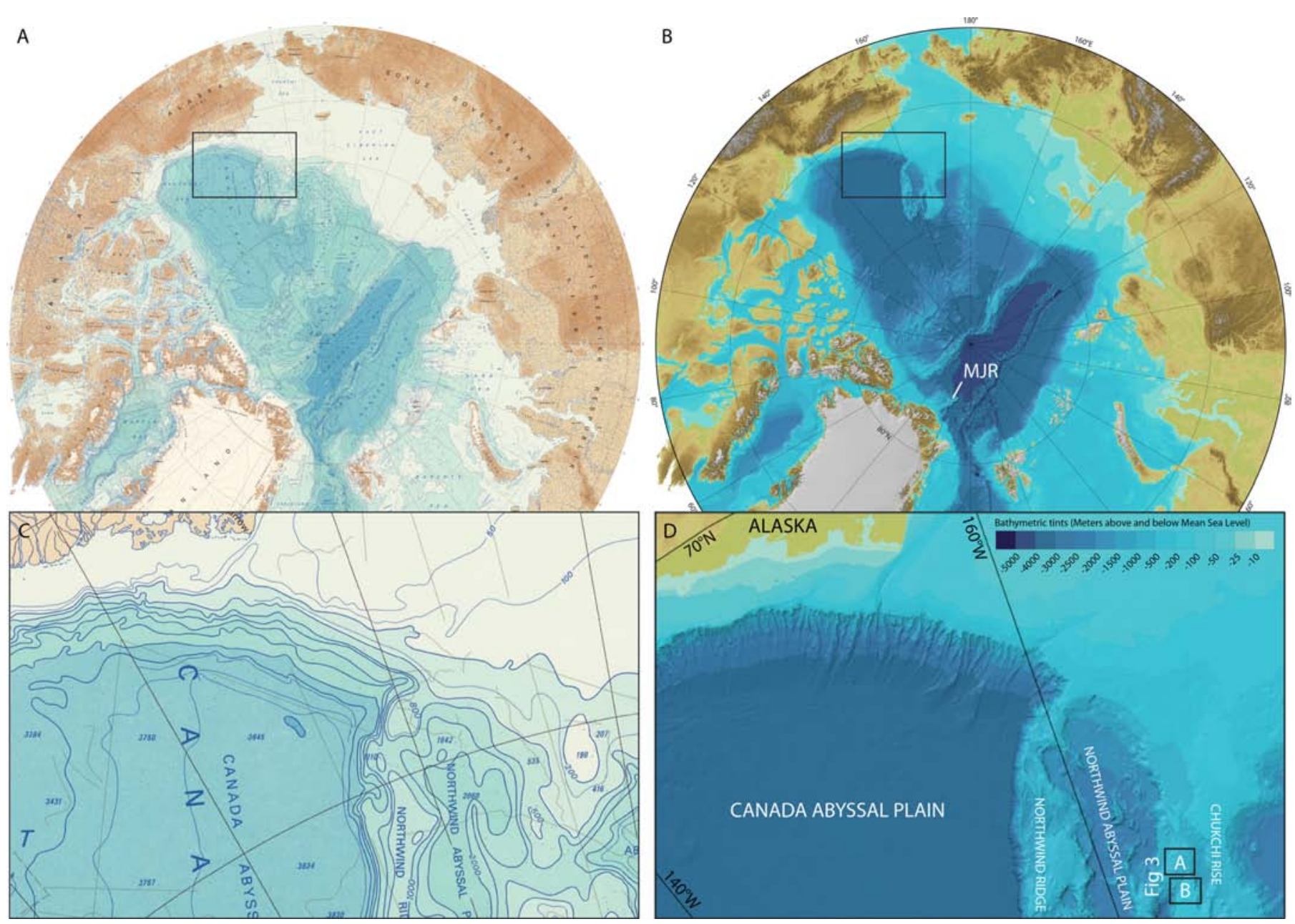

FIG. 1. Comparison between (A) the GEBCO Sheet 5.17 contour map (Canadian Hydrographic Service, 1979) and (B) the International Bathymetric Chart of the Arctic Ocean (IBCAO) Version 3.0 (Jakobsson et al., 2012). In Panel B, MJR indicates the Morris Jesup Rise north of Greenland. Black rectangles in Panels A and B indicate the area enlarged below, which shows the bathymetry over the northern Alaskan margin and adjacent Northwind Ridge and Chukchi Rise as portrayed in both (C) Sheet 5.17 and (D) IBCAO. The black boxes at lower right in panel D outline the locations of the 3D views shown in Figure 2, which reveal the large difference in bathymetric information between those two bathymetric products (see text for discussion).

geochemical processes, and biological activity with the seafloor. Bathymetry guides bottom currents (Björk et al., 2007), influences mixing (Nycander, 2005), and is a critical constraint on bottom habitat (Dunn and Halpin, 2009). It has recently been shown that bathymetry also greatly influences Arctic sea-ice formation and seasonal evolution through its control of the distribution and mixing of warm and cold water masses (Nghiem et al., 2012). Observations of ocean currents, temperature, biological production and diversity, and chemical and physical properties invariably require a description of the seafloor's shape in order to be fully understood.

In 1997, the International Bathymetric Chart of the Arctic Ocean (IBCAO) project was initiated in St. Petersburg, Russia. The project's main objective was to collect all available bathymetry data for the compilation of the most upto-date bathymetric portrayal of the Arctic Ocean seafloor (Macnab and Grikurov, 1997). IBCAO began by building on the database established during the compilation of the General Bathymetric Chart of the Oceans (GEBCO) Sheet 5.17, a bathymetric contour map of the Arctic Ocean above $64^{\circ} \mathrm{N}$ (Canadian Hydrographic Service, 1979) (Fig. 1). This database did not contain many soundings because research icebreakers had not ventured far into the pack ice at that time.

Three years after the 1997 St. Petersburg meeting, a first digital bathymetric compilation portraying the Arctic Ocean seafloor was completed and released to the public (Jakobsson et al., 2000). IBCAO has since served as the base bathymetry for numerous ocean circulation modeling experiments (e.g., Maslowski and Walczowski, 2002; Padman and Erofeeva, 2004; Maltrud and McClean, 2005; Manizza et al., 2011) and in projects involving direct analyses of the Arctic Ocean seafloor or where detailed analyses of higher resolution local bathymetric surveys must be placed in a regional context (e.g., Minakov et al., 2012; Rajan et al., 2012). At the time of release of the latest IBCAO Version 3.0 in 2012, approximately $11 \%$ of the Arctic Ocean seafloor had been mapped with modern multibeam echo sounders (Jakobsson et al., 2012), which shows that the work of describing the Arctic Ocean seafloor is still in its infancy. In comparison, $\sim 15.4 \%$ of seafloor south 
of $60^{\circ} \mathrm{S}$ is portrayed using multibeam data in the recently released International Bathymetric Chart of the Southern Ocean (IBCSO) (Arndt et al., 2013). There is no up-to-date published assessment of the proportion of the entire world ocean floor that has been mapped using multibeam echo sounders.

This paper provides a brief mapping history of the Arctic Ocean, describes the current status of Arctic Ocean bathymetric mapping activities, and illustrates the need for an improved portrayal of the seafloor, in particular in the more remote central Arctic Ocean. While we specifically discuss the need for bathymetry, data on other parameters such as gravity, magnetics, and geology, which can often be collected at the same time as bathymetry data, may also be required in order to establish an appropriate geospatial framework for observations of Earth system parameters.

\section{DEVELOPMENT OF AN ARCTIC OCEAN BATHYMETRIC FRAMEWORK}

Fridtjof Nansen compiled a bathymetric map that portrayed the central Arctic Ocean as a single deep featureless basin from a handful of lead line soundings acquired during the Fram Expedition of 1893-96 (Nansen, 1907). These soundings were carried out along the drift path of Fram, the ice-strengthened ship that had been purposely frozen into the pack ice and left to drift from northwest of the New Siberian Islands across the Arctic basin to what is now known as the Fram Strait, between Svalbard and Greenland. Nansen's map still represents the single largest step forward in Arctic Ocean bathymetric mapping. Before its publication, many believed that the North Pole area was composed of land, as depth measurements had not been made in the region.

Subsequent bathymetric maps successively revealed a complex seafloor, shaped by the tectonic evolution of the Arctic Basin, ocean currents, and glacial history (e.g., Atlasov et al., 1964; Canadian Hydrographic Service, 1979; Perry et al., 1986). These early maps were made from a sparse collection of lead-line or single-beam echo sounder measurements. Even with the addition of soundings collected from the first batch of U.S. submarine transits beneath the sea, the database allowed only a broad regional interpretation of the general bathymetric trends, typically displayed as contours.

As more sounding data became available, it became feasible for the IBCAO project to produce a more detailed gridded product. In particular, the released data included additional echo soundings collected by American and British nuclear submarines and by six scientific submarine cruises in 1993-99 of the SCience ICe EXercise (SCICEX) project (Newton, 2000), which incorporated a specialized swath-mapping system on the submarine USS Hawkbill (Edwards and Coakley, 2003).

The gridding process uses each sounding to produce a statistical estimate of the depth in a local region pre-defined by the grid cell spacing (GEBCO, 2014). Depending on the density and spatial arrangement of the underlying sounding data set, the depth determined for the grid cell at a defined point (the grid node) is some form of average (e.g., a mean, weighted mean, or median) of all soundings in a pre-defined region around the grid node or, if no data exist in the predefined region, an interpolation between surrounding grid nodes. The result of this process is a digital bathymetric model (DBM) that typically has a much higher resolution than a broadly interpolated contour plot and is ideally suited for display with 3-D visualization tools. Digital Terrain Model (DTM) is a standard term used to describe a digital grid representing a terrain surface, and a DBM is an underwater version. It is only through these higher-resolution digital products that we can discern processes like the interaction of deep ocean currents or ice.

The goal of the IBCAO project was to produce an Arctic DBM. The first version of IBCAO (Version 1.0) used a grid cell spacing of $2.5 \times 2.5 \mathrm{~km}$ on a polar stereographic projection. Version 2.0 incorporated more data and was completed at a finer grid spacing of $2 \times 2 \mathrm{~km}$ on the same polar stereographic projection used for the first version (Jakobsson et al., 2008a). Since the first release, IBCAO has been widely used for a broad range of applications. In Version 3.0 , released in 2012, the resolution was increased to $500 \times$ $500 \mathrm{~m}$ grid spacing (Jakobsson et al., 2012). This DBM has been incorporated as the Arctic Ocean standard bathymetry in the global one-minute bathymetric grid assembled by GEBCO (Intergovernmental Oceanographic Commission et al., 2003) as well as in the one-minute ETOPO1 and twominute ETOPO2 grids (NGDC, 2006; Amante and Eakins, 2009). Version 3.0 is the representation of the Arctic Ocean seafloor used by Google Earth ${ }^{\mathrm{TM}}$.

\section{FROM THE REGIONAL SHAPE OF THE SEAFLOOR FORM TO EXPLICIT DETAIL}

A traditional bathymetric contour map provides a crude view of the seafloor shape. GEBCO Sheet 5.17 of the Arctic Ocean is a good example (Fig. 1). A closer view of the northern Alaskan continental shelf and slope and the adjacent Northwind Ridge and Chukchi Rise shows that it is barely possible from the bathymetric contours to see where the shallow Alaskan continental shelf break is located (Fig. 1C). The pronounced gullies visible in IBCAO along the Alaskan continental slope are not at all portrayed by the contours of Sheet 5.17 (Figs. 1C and D). Gridding the GEBCO contours and visualizing the DBM in 3D does not help because detailed bathymetric source information was not available to the cartographer drawing the contours in the first place (Fig. 2). GEBCO Sheet 5.17 was based on singlebeam soundings collected mainly along sparse submarine tracklines or drifting ice stations, and these soundings were insufficient to capture the bathymetric details. The data were so scarce that the contour interval on 5.17 was $500 \mathrm{~m}$, resulting in coarse vertical resolution. Features that cannot 


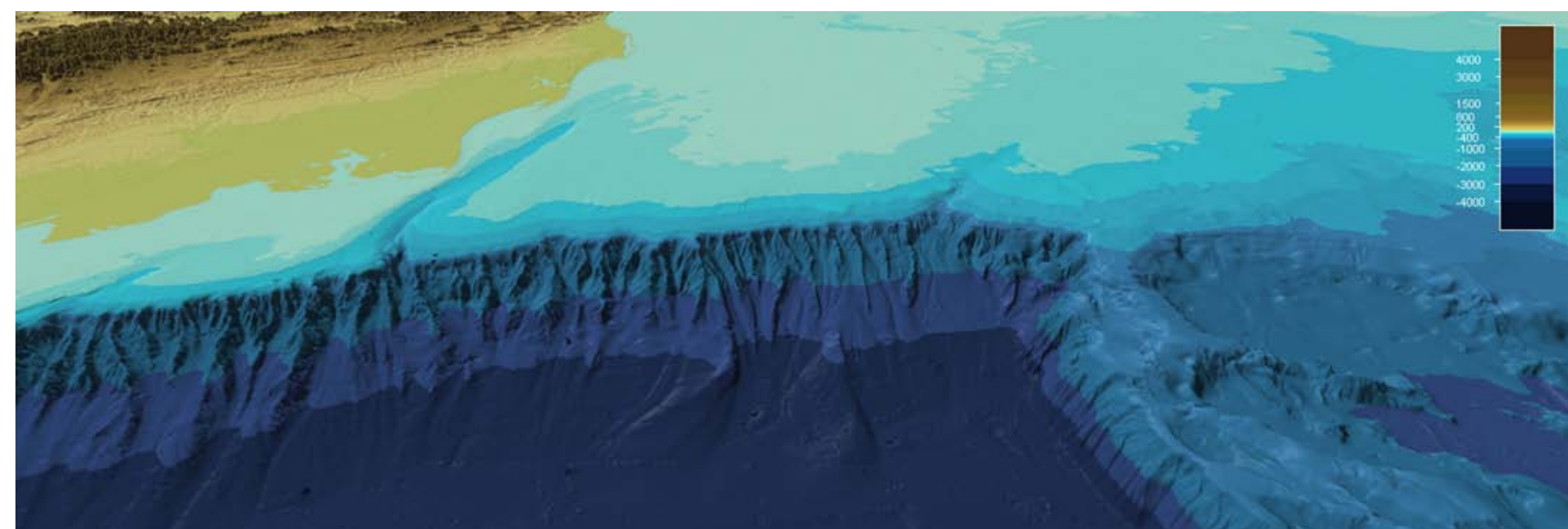

IBCAO Version 3.0

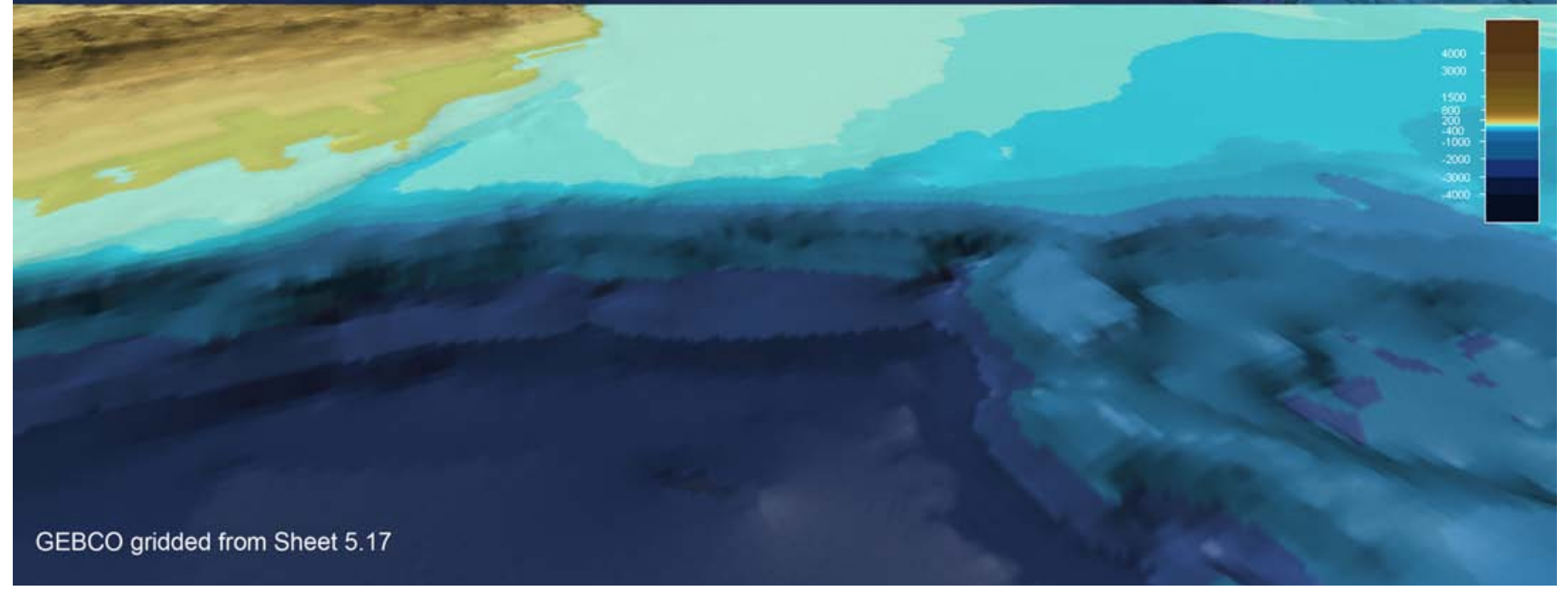

FIG. 2. 3D views of the northern Alaskan margin and adjacent Northwind Ridge and Chukchi Rise. Locations of the views are shown in Figure 1. Gullies formed in the Alaskan continental slope are clearly visible in the IBCAO Version 3 compilation while they are not seen in the grid produced from Sheet 5.17 depth contours (lower panel, see text for discussion).

be portrayed at this resolution include the relatively large gullies that have formed on the northern Alaskan slope, with ca. $15 \mathrm{~km}$ between thalwegs and bathymetric expressions of commonly less than $500 \mathrm{~m}$. These features were first revealed after multibeam mapping carried out during the U.S. mapping program to substantiate an extended continental shelf as set out in Article 76 of the United Nations Convention on the Law of the Sea (UNCLOS) (Mayer and Armstrong, 2011). The acquired multibeam data were placed in the public domain and could therefore be used in the compilation of IBCAO Version 3.0.

The steepness of a continental slope greatly affects the speed of boundary currents flowing along it (e.g., Speich et al., 2006): currents flow faster along a steeper slope. In extreme cases, with sharp turning and very steep bathymetry, a boundary current may even separate and release from its topographic steering and generate eddies. This process has been shown to occur around the Morris Jesup Rise, which protrudes northward into the Amundsen Basin from the northern Greenland margin (Fig. 1B) (Björk et al.,
2010). It was not until the Morris Jesup Rise was mapped with the multibeam installed in the Swedish icebreaker Oden that the steep walls of this bathymetric feature were discovered in full (Jakobsson et al., 2008b). These examples illustrate the importance of having an accurate representation of the bathymetry in ocean general circulation experiments.

There are of course numerous seafloor features beyond the limit that can be resolved with the $500 \times 500 \mathrm{~m}$ IBCAO DBM. The original multibeam data, used in IBCAO over large areas of the Chukchi Borderland, were collected with USCGC Healy during the U.S. UNCLOS mapping program (Mayer and Armstrong, 2011). These original multibeam data, gridded at a resolution of $15 \times 15 \mathrm{~m}$, reveal abundant pockmarks and glacial grooves, resembling so-called MegaScale Glacial Lineations (MSGL), features that are not visible in the coarser IBCAO (Fig. 3). The pockmarks may be an indication of gas hydrate destabilization in this area, while the MSGL-like features constitute an imprint of ice grounding, possible even signifying an extensive local ice 


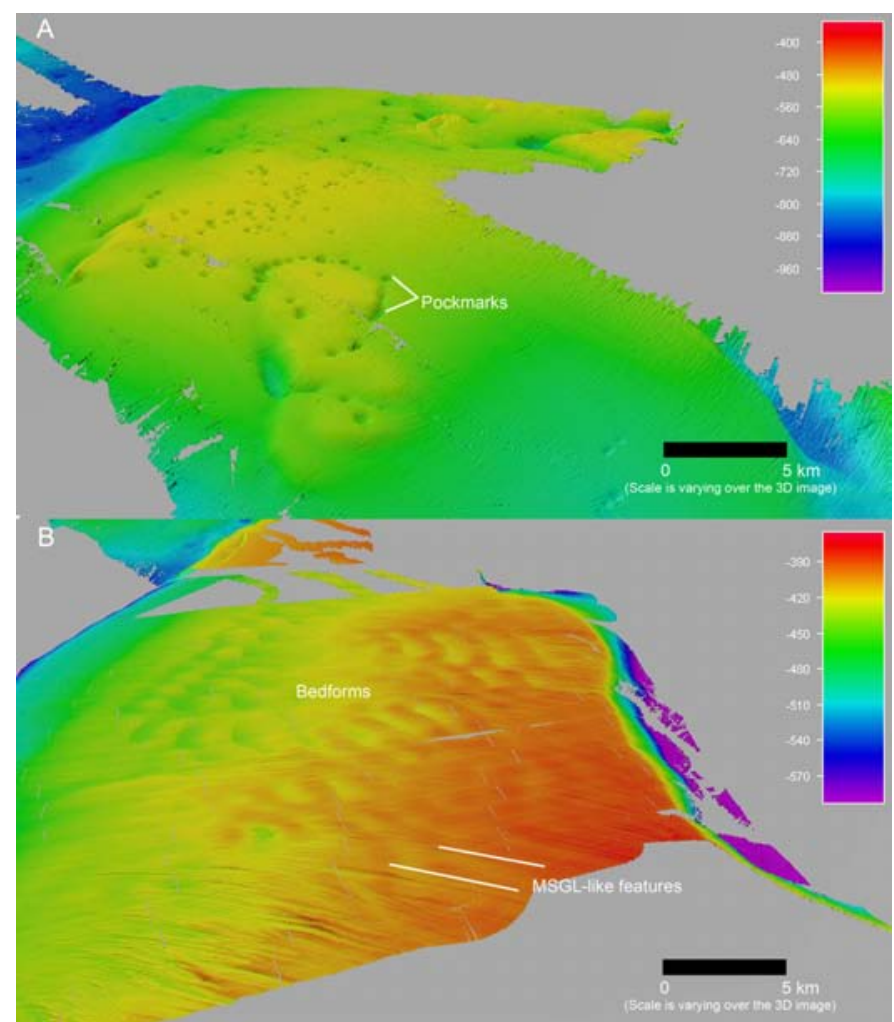

FIG. 3. The upper panel (A) shows pronounced pockmarks in the Chukchi Rise that are not visible in the $500 \times 500 \mathrm{~m} \mathrm{IBCAO}$ grid. In the lower panel (B), the bathymetry shows signs of past glacial activity. Glacial features resembling Mega-Scale Glacial Lineations (MSGLs), which indicate past flows of grounded ice masses, can be seen, as well as conspicuous bedforms that cut into these lineations. The multibeam bathymetric data shown in both panels were collected with USCGC Healy during the U.S. UNCLOS cruises (Mayer and Armstrong, 2011). These data were gridded at a resolution of $15 \times 15 \mathrm{~m}$ rise that formed over the Northwind Ridge and the Chukchi Rise during past glacial periods (Jakobsson et al., 2010). Also visible in Figure 3B are conspicuous bedforms on the shallow Chukchi Rise crest that are most likely linked to past glacial activity, but which will require further investigations in order to be understood. Grounding of contemporary icebergs may also sculpt the seafloor, which implies that mapped scours constitute critical information for any offshore activity involving seafloor installations.

The newest generation of multibeam sonars allows for mapping and visualization of features in the water column, as well as providing the bathymetric context. While NOAA's vessel of exploration Okeanos Explorer was steaming into port after the initial onboard sea trials of a new Kongsberg EM302 multibeam sonar, the new water column-capable sonar revealed a remarkable column of gas bubbles $1400 \mathrm{~m}$ high emanating from a slump scarp in approximately $2000 \mathrm{~m}$ of water (Gardner et al., 2009) (Fig. 4). The vessel returned several weeks later to see how ephemeral the seep was. The NOAA Ocean Exploration team not only found that the seep was still there, but also was able to map a series of additional seeps all exhibiting the same behavior (emanating from the seafloor at about $2000 \mathrm{~m}$ depth, rising through the water column, and disappearing at a depth of about 500-600 m below the seasurface (M. Malik, pers. comm. 2013). Such behavior indicates that a seep is composed of methane bubbles, which should go into solution in the undersaturated (with respect to methane) ocean waters, but instead are protected by a methane hydrate coating that forms at the seafloor. The coating keeps the methane from going into solution until the bubbles reach the hydrate instability zone between 500 and

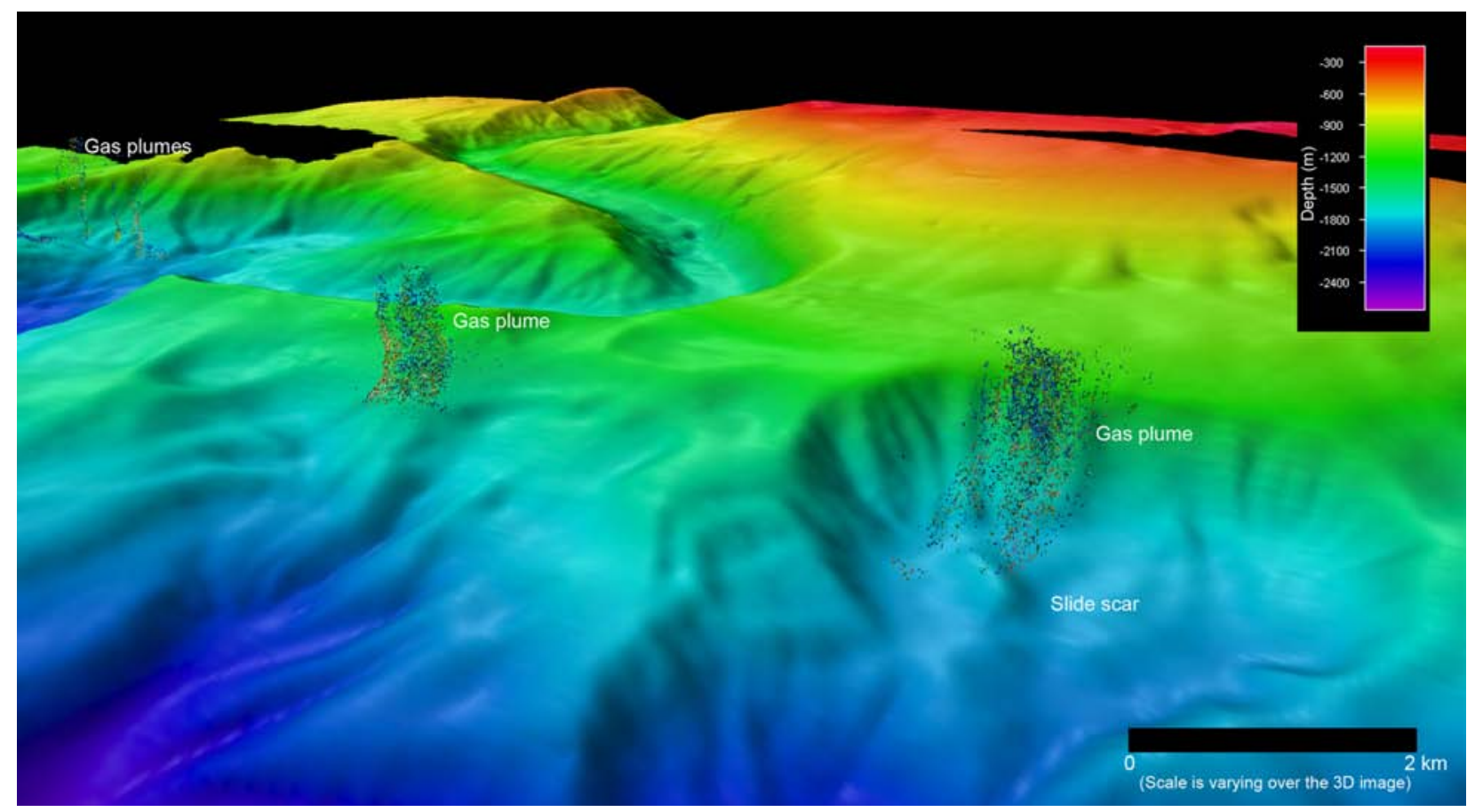

FIG. 4. NOAA's vessel of exploration Okeanos Explorer multibeam-mapped gas seeps off the northern California margin (Gardner et al., 2009). Note that the seeps are related to slump scarps seen in the bathymetry. 
$600 \mathrm{~m}$ below the surface, and once the coating dissolves, the methane goes into solution (Brewer et al., 1998) and disappears as an acoustic target. Capabilities like this open up an entirely new world of high-resolution, swath-based water column mapping that includes the direct mapping of fisheries targets and physical oceanographic processes.

\section{CONCLUSIONS}

Despite the importance of an accurate, high-resolution portrayal of ocean bathymetry, we currently know the topography of the moon and Mars (Mazarico et al., 2011) with better accuracy and resolution. This is particularly true for the pack ice-covered Arctic Ocean: huge portions of the most severely ice-covered areas (those north of Greenland, for example) have never been visited by icebreakers. The few existing bathymetric soundings from these areas have been collected by submarines, from the drifting pack ice, from ice-stations, or during aircraft landings. It appears that parts of the Arctic Ocean such as the region north of Greenland have areas larger than several American states that have not been observed. In order for all Arctic marine activities to benefit fully from the substantial improvement that today's bathymetric mapping systems provide, the entire Arctic Ocean must eventually be ensonified with modern and accurate methods. To expedite the acquisition of bathymetric data, we recommend that all agencies collecting data in the Arctic liaise with IBCAO / GEBCO to:

1) Establish the scientific needs for improved knowledge of ocean bathymetry;

2) Specify their accuracy and resolution requirements;

3) Identify actions and priorities (such as what parts of the Arctic should be mapped first);

4) Inspire collaboration between the scientific community and industry (even release of single-beam echo soundings collected during industry seismic surveys will be useful to improve our current knowledge of the seafloor's shape in the Arctic Ocean).

\section{REFERENCES}

Amante, C., and Eakins, B.W. 2009. ETOPO1 1 arc-minute global relief model: Procedures, data sources and analysis. NOAA Technical Memorandum NESDIS NGDC-24. Boulder, Colorado: National Geophysical Data Center, National Oceanic and Atmospheric Administration. $19 \mathrm{p}$.

http://www.ngdc.noaa.gov/mgg/global/relief/ETOPO1/docs/ ETOPO1.pdf

Arndt, J.E., Schenke, H.W., Jakobsson, M., Nitsche, F.O., Buys, G., Goleby, B., Rebesco, M., et al. 2013. The International Bathymetric Chart of the Southern Ocean (IBCSO) Version 1.0-A new bathymetric compilation covering circum-Antarctic waters. Geophysical Research Letters 40(12):3111-3117.

http://dx.doi.org/10.1002/grl.50413
Atlasov, I.P., Vakar, V.A., Dibner, V.P., Egyazarov, B.Kh., and Zimkin, A.B. 1964. A new tectonic chart of the Arctic. Ottawa, Ontario: Directorate of Scientific Information Services.

Björk, G., Jakobsson, M., Rudels, B., Swift, J.H., Anderson, L.G., Darby, D.A., Backman, J., et al. 2007. Bathymetry and deep-water exchange across the central Lomonosov Ridge at 88-89 N. Deep-Sea Research Part I 54(8):1197-1208.

http://dx.doi.org/10.1016/j.dsr.2007.05.010

Björk, G., Anderson, L.G., Jakobsson, M., Antony, D., Eriksson, B., Eriksson, P.B., Hell, B., et al. 2010. Flow of Canadian Basin deep water in the Western Eurasian Basin of the Arctic Ocean. Deep Sea Research Part I 57(4):577-586. http://dx.doi.org/10.1016/j.dsr.2010.01.006

Brewer, P.G., Orr, F.M., Friederich, G., Kvenvolden, K.A., and Orange, D.L. 1998. Gas hydrate formation in the deep sea: In situ experiments with controlled release of methane, natural gas, and carbon dioxide. Energy \& Fuels 12(1):183-188. http://dx.doi.org/10.1021/ef970172q

Canadian Hydrographic Service. 1979. General bathymetric chart of the oceans (GEBCO), Sheet 5.17; map 1:6,000,000. Ottawa: Canadian Hydrographic Service.

Dunn, D.C., and Halpin, P.N. 2009. Rugosity-based regional modeling of hard-bottom habitat. Marine Ecology Progress Series 377:1-11. http://dx.doi.org/10.3354/meps07839

Edwards, M.H., and Coakley, B.J. 2003. SCICEX investigations of the Arctic Ocean system. Chemie der Erde - Geochemistry 63(4):281-328.

http://dx.doi.org/10.1078/0009-2819-00039

Gardner, J.V., Malik, M., and Walker, S. 2009. Plume 1400 meters high discovered at the seafloor off the northern California margin. EOS, Transactions of the American Geophysical Union 90(32):275.

http://dx.doi.org/10.1029/2009EO320003

GEBCO (General Bathymetric Chart of the Oceans). 2014. IHO-IOC GEBCO cook book. In: Marks, K., ed. Monaco: International Hydrographic Organization. 294 p. http://www.gebco.net/data_and_products/gebco_cook_book/

Intergovernmental Oceanographic Commission, International Hydrographic Organization, and British Oceanographic Data Centre. 2003. The centenary edition of the GEBCO digital atlas. Liverpool: British Oceanographic Data Centre.

Jakobsson, M., Cherkis, N., Woodward, J., Macnab, R., and Coakley, B. 2000. New grid of Arctic bathymetry aids scientists and mapmakers. EOS, Transactions American Geophysical Union 81(9):89-96. http://dx.doi.org/10.1029/00EO00059

Jakobsson, M., Macnab, R., Mayer, L., Anderson, R., Edwards, M., Hatzky, J., Schenke, H.W., and Johnson, P. 2008a. An improved bathymetric portrayal of the Arctic Ocean: Implications for ocean modeling and geological, geophysical and oceanographic analyses. Geophysical Research Letters 35, L07602.

http://dx.doi.org/10.1029/2008GL033520

Jakobsson, M., Marcussen, C., and LOMROG Scientific Party. 2008b. Lomonosov Ridge off Greenland 2007 (LOMROG): Cruise report. Special Publication. Copenhagen: Geological Survey of Denmark and Greenland. 122 p. 
Jakobsson, M., Nilsson, J., O’Regan, M., Backman, J., Löwemark, L., Dowdeswell, J.A., Mayer, L., et al. 2010. An Arctic Ocean ice shelf during MIS 6 constrained by new geophysical and geological data. Quaternary Science Reviews 29(2526):3505-3517.

http://dx.doi.org/10.1016/j.quascirev.2010.03.015

Jakobsson, M., Mayer, L., Coakley, B., Dowdeswell, J.A., Forbes, S., Fridman, B., Hodnesdal, H., et al. 2012. The International Bathymetric Chart of the Arctic Ocean (IBCAO) Version 3.0. Geophysical Research Letters 39, L12609. http://dx.doi.org/10.1029/2012GL052219

Macnab, R., and Grikurov, G., 1997. Report: Arctic Bathymetry Workshop. 18-19 September 1997, Institute for Geology and Mineral Resources of the Ocean (VNIIOkeangeologia), St. Petersburg, Russia. Geological Survey of Canada Open File 3569. 38 p. http://dx.doi.org/10.4095/209403

Maltrud, M.E., and McClean, J.L. 2005. An eddy resolving global 1/10 ocean simulation. Ocean Modelling 8(1-2):31-54. http://dx.doi.org/10.1016/j.ocemod.2003.12.001

Manizza, M., Follows, M.J., Dutkiewicz, S., Menemenlis, D., McClelland, J.W., Hill, C.N., Peterson, B.J., and Key, R.M. 2011. A model of the Arctic Ocean carbon cycle. Journal of Geophysical Research 116, C12020. http://dx.doi.org/10.1029/2011JC006998

Maslowski, W., and Walczowski, W. 2002. Circulation of the Baltic Sea and its connection to the Pan-Arctic region - a large scale and high-resolution modeling approach. Boreal Environmental Research 7:319-325. http://www.borenv.net/BER/pdfs/ber7/ber7-319.pdf

Mayer, L.A., and Armstrong, A.A. 2011. U.S. Law of the Sea cruise to map the foot of the slope and 2500-m isobath of the U.S. Arctic Ocean margin. Durham, New Hampshire: Center for Coastal and Ocean Mapping (CCOM)/Joint Hydrographic Center (JHC). 235 p.

Mazarico, E., Rowlands, D.D., Neumann, G.A., Smith, D.E., Torrence, M.H., Lemoine, F.G., and Zuber, M.T. 2011. Orbit determination of the Lunar Reconnaissance Orbiter. Journal of Geodesy 86(3):193-207. http://dx.doi.org/10.1007/s00190-011-0509-4
Minakov, A., Faleide, J.I., Glebovsky, V.Yu., and Mjelde, R., 2012. Structure and evolution of the northern Barents-Kara Sea continental margin from integrated analysis of potential fields, bathymetry and sparse seismic data. Geophysical Journal International 188(1):79-102. http://dx.doi.org/10.1111/j.1365-246X.2011.05258.x

Nansen, F. 1907. On North Polar problems. The Geographical Journal 30(5):469-487. http://dx.doi.org/10.2307/1778052

Newton, G.B. 2000. The Science Ice Exercise Program: History, achievements, and future of SCICEX. Arctic Research of the United States 14(Fall/Winter):2-7.

NGDC (National Geophysical Data Center). 2006. 2-minute gridded global relief data (ETOPO2v2). Boulder, Colorado: NGDC, National Oceanic and Atmospheric Administration, U.S. Department of Commerce.

Nghiem, S.V., Clemente-Colón, P., Rigor, I.G., Hall, D.K., and Neumann, G. 2012. Seafloor control on sea ice. Deep Sea Research Part II 77-80:52-61. http://dx.doi.org/10.1016/j.dsr2.2012.04.004

Nycander, J. 2005. Generation of internal waves in the deep ocean by tides. Journal of Geophysical Research 110, C10028. http://dx.doi.org/10.1029/2004JC002487

Padman, L., and Erofeeva, S. 2004. A barotropic inverse tidal model for the Arctic Ocean. Geophysical Research Letters 31, L02303. http://dx.doi.org/10.1029/2003GL019003

Perry, R.K., Fleming, H.S., Weber, J.R., Kristoffersen, Y., Hall, J.K., Grantz, A., Johnson, G.L., Cherkis, N.Z., and Larsen, B. 1986. Bathymetry of the Arctic Ocean. Map and Chart Series, MC-56. Boulder, Colorado: Geological Society of America.

Rajan, A., Mienert, J., and Bünz, S. 2012. Acoustic evidence for a gas migration and release system in Arctic glaciated continental margins offshore NW-Svalbard. Marine and Petroleum Geology 32(1):36-49. http://dx.doi.org/10.1016/j.marpetgeo.2011.12.008

Speich, S., Lutjeharms, J.R.E., Penven, P., and Blanke, B. 2006. Role of bathymetry in Agulhas Current configuration and behaviour. Geophysical Research Letters 33, L23611. http://dx.doi.org/10.1029/2006GL027157 